\title{
Письмо редактора
}

Завершающий 4-й номер ИНТЕРа в 2020 году, наверное, мог бы получить обобщающее название «Время». Социальное время отличают неравномерность, возможность ускоряться, замедляться, даже как бы останавливаться, возобновляя движение по кругу. Вспомним линейное время подвигов мифического героя Одиссея и циклическое время ожидающей его Пенелопы, вяжущей и распускающей ковер. Но, не подменяя понятия времени и движения, мы распознаем в потоке времени движение событий. В качественной социологии событийность имеет важное значение, поскольку за выделением события индивидом стоит герменевтическое усилие. А своими действиями социальные акторы придают времени ощутимую форму. Ведь то, что индивиды при помощи своих действий воспроизводят социальную реальность с ее институтами и практиками, обеспечивает социальной реальности ее протяженность во времени. Разноукладность времени - сложный многоуровневый сюжет. Мы обнаруживаем у Э. Гидденса, что длящаяся социальная жизнь включает три пересекающиеся уровня времени: 1) durée of the day-today experience (темпоральность непосредственного опыта в повседневной жизни), 2) Dasein (темпоральность человеческой жизни и ее циклов), 3) longue durée of institutions (долгая длительность, связанная с воспроизводством социальных институций) (Giddens, 1981: 93). Драматичной характеристикой этого года для всех (!) стал уникальный опыт пандемии, который перемешал темпоральности как повседневности, так и привычной цикличности жизни, а также институций.

Поэтому мы привлекаем внимание читателей к этому понятию не только вводной статьей теоретического характера - В.К. Шеллер «Понимание, видение и репрезентация времени в темпографии», но и несколькими эссе-размышлениями социологов о сложном времени пандемии. Это эссе А. Героса о конфликте между здоровьем, экономикой и правами человека, эссе М.-К. Дёблер, которая переосмысляет привычные телесные практики в условиях вынужденной социальной дистанции, а также текст Ч. Фанг о том, как воспринимаются крайний экзистенциальный сюжет - смерть - и практики горевания в контексте пандемии.

Дальнейшее содержание номера в разделе полевых исследований представлено анализом практик чтения при выборе между бумажными и электронными носителями (статья И. А. Чудовой). Как рационализируют свои предпочтения в этом вопросе студенты и преподаватели и научные сотрудники? Другой текст - Т. Ю. Ларкиной - касается сложного вопроса конструирования родственных уз через услуги, оказываемые бездетным родителям репродуктивными агентствами. Социально-конструктивистская логика исследования обнаруживает процесс, дискурсивно разрывающий 
родство между донорами клеток и ребёнком, но при этом легитимирующий родственность заказчиков услуги и ребёнка. Еще одна статья (И. Камара и И. Траоре) посвящена исследованию факторов успеваемости в представлении участников образовательного процесса в школах Республики Мали.

В заключение номера мы поддерживаем новым текстом рубрику ИНТЕРэнциклопедии качественных методов, на этот раз освещая методологию и методику нарративного интервью (Е.Ю. Рождественская). Приглашаем исследователей, глубоко разбирающихся в тех или иных качественных методах, направлять в эту энциклопедию свои статьи.

\section{Литература}

Giddens A. Time and Space in Social Theory // Lebenswelt und soziale Probleme: Verhandlungen des 20. Deutschen Soziologentages zu Bremen 1980 / Ed. by J. Matthes. Frankfurt am Main: Campus Verl, 1981. P. 88-97.

Ответственный редактор номера, Елена Рождественская 